\title{
ANALISIS PENERAPAN GOOD CORPORATE GOVERNANCE TERHADAP KINERJA KEUANGAN PADA PERUSAHAAN PERBANKAN YANG TERDAFTAR DI BURSA EFEK INDONESIA PERIODE 2014-2017
}

\author{
Nadya Ayu Saputri , Rochmi Widayanti, Ratna Damayanti \\ Universitas Islam Batik Surakarta \\ Email : nadya.ayu@gmail.com
}

\begin{abstract}
The purpose of the study was to analyze the effect of the application of good corporate governance, which was governed by the board of commissioners, board of directors, audit committee and institutional ownership of financial performance which was interpreted by the return on asset ratio in banking companies on the Indonesia Stock Exchange for the period 2014-2017. The total population is 43 companies, using purpose sampling techniques obtained by a sample of 25 companies. While the analysis technique used is multiple linear regression. The results show that only the audit committee that has no significant effect, the board of commissioners has a significant negative effect on the board of directors and institutional ownership has a significant positive effect on financial performance. Other results show that simultaneous application of good corporate governance has a significant influence on financial performance.
\end{abstract}

Keyword: good corporate governance, financial performance.

Abstrak : Tujuan penelitian dilakukan untuk menganalisis pengaruh penerapan good corporate governance yang diperoksikan dengan dewan komisaris, dewan direksi, komite audit dan kepemilikan institusional terhadap kinerja keuangan yang diperoksikan dengan rasio return on asset pada perusahaan perbankan di BEI periode 2014-2017. Jumlah populasi yaitu 43 perusahaan, dengan menggunakan teknik purpose sampling diperoleh sampel 25 perusahaan. Sedangkan teknik analisis yang digunakan yaitu regresi linier berganda. Hasil analisis data, diperoleh hasil bahwa hanya komite audit yang tidak berpengaruh signinifikan, dewan komisaris berpengaruh negatif signifikan direksi dan kepemilikan institusional berpengaruh positif signifikan terhadap kinerja keuangan. Hasil lain menunjukkan bahwa secara simultan penerapan good corporate governance memiliki pengaruh signifikan terhadap kinerja keuangan.

Kata kunci: good corporate governance, kinerja keuangan.

\section{PENDAHULUAN}

Pesatnya perkembangan bisnis, diiringi dengan kemajuan ilmu pendididikan dan teknologi, mengakibatkan adanya suatu persaingan persaingan dalam bisnis. Sehingga diperlukan tata kelola yang tepat bagi perusahaan untuk dapat bersaing. Good corporate governance (GCG) adalah suatu tata kelola perusahaan dengan prinsip-prinsip seperti keterbukaan, pertanggungjawaban, akuntabilitas, independensi dan kewajaran (Masitoh dan Hidayah, 2017).

Peraturan Bank Indonesia No.13/1/PBI/2011, untuk menilai kinerja atau kesehatan perusahaan perbankan dapat menggunakan analisis penilaian RGEC (Risk Profile, Good Corporate Governance, Earnings, Capital). Good Corporate Governance sebagai salah satu unsur RGEC yang dapat digunakan untuk menilai kesehatan perbankan. Kesehatan perbankan dianggap penting karena, jika 
dilihat pada saat terjadinya krisis moneter tahun 1997, kinerja perbankan dinilai cukup buruk dan kesehatan perbankan tidak termonitor dengan baik (Marjono dan Ningsih, 2016). Menurut Budiyono \& Wulansari (2018) komposisi dewan komisaris, kepemilikan institusi dan kepemilikan manajerial berpengaruh terhadap nilai perusahaan. Leverage dan Profitability juga berpengaruh terhadap pengungkapan CSR (Budiyono \& Dewi, 2017).

Kebijakan pemerintah pada saat itu yaitu dengan melakukan penutupan bank, sebanyak 9 dilakukan rekapitulasi, 7 bank dilakukan pengambilalihan, dan sebanyak 73 bank dipertahankan untuk menjalankan operasionya. Sehingga pada tahun 2001 hanya tersisa 151 bank yang masih tetap beroperasi. Selain itu pada Januari 2004, diumumkannya implementasi Arsitektur Perbankan Indonesia (API) oleh Bank Indonesia, sebagai upaya pembenahan pada industri perbankan dan membangun kembali perekonomian Indonesia. Keseriusan pemerintah Indonesia dalam melakukan pembenahan dan menjaga kesehatan perbankan, dibuktikan dengan adanya paket kebijakan yang lebih dikenal Pakjan 2006 pada tanggal 30 Januari 2006, dimana isi dalam kebijakan tersebut salah satunya mengatur tentang pelaksanaan good corporate governance (Aprianingsih, 2016).

\section{KAJIAN TEORI}

\section{Good Corporate Governance}

Good corporate governance yaitu sistem dimana penerapannya digunakan untuk mengarahkan dan mengendalikan kegiatan perusahaan, agar tercapainya keseimbangan kewenangan perusahaan dengan kekuatan (Sutedi, 2012:1). Pelaksanaan good corporate governance, perusahaan harus memiliki pihak yang dapat menjamin fungsi good corporate governance yang baik, salah satunya berasal dari dalam perusahaan atau internal perusahaan. Unsur internal good corporate governance dapat meliputi dewan komisaris, dewan direksi, komite audit dan kepemilikan institusional (Marjono dan Ningsih, 2016 ; Istighfarin dan Wirawati, 2015).

Unsur yang pertama yaitu dewan komisaris. Dewan komisaris adalah anggota peruahaan yang memiliku tugas dan tanggungjawab dalam pengawasan baik pengawasan yang bersifat umum maupun pengawasan yang khusus dengan berdasarkan anggaran dasar (Agoes dan Ardana, 2014:108). Keberadaan dewan komisaris dalam perusahaan, diharapkan dapat memberikan nasihat kepada direksi dan manejemen dalam menghadapi suatu permasalahan.

Unsur selanjutnya yaitu dewan direksi. Direksi anggota dalam perusahaan yang memiliki tugas dan tanggungjawab dalam melakukan pengurusan perusahaan (Kuswiranto, 2016:29). Sebagai pengurus perseroan, direksi merupakan agen dari perseroan, sehingga tidak dapat bertindak sesuka hati. Unsur yang ketiga yaitu komite audit. Komite audit dalam perusahaan mempunyai tugas untuk membantu kegiatan komisaris, yaitu kertait dengan melakukan pengawasan pelaksaan pengelolaan perusahaan dengan baik (Kuswiratmo, 2016:75).

Sedangkan unsur yang keempat yaitu kepemilikan institusional. Kepemilikan institusional adalah perusahaan-perusahaan yang berinvestasi dengan menggunakan nama perusahaan atau atas nama perusahaan (Setianto, 2016:41). Terkait demikian, manager akan merasakan adanya pengawasan yang lebih ketat jika kepemilikan institusional perusahaan semakin tinggi.

\section{Kinerja Keuangan}

Kinerja keuangan merupakan gambaran dari pencapaian keberhasilan perusahaan yang dapat diartikan sebagai hasil yang telah dicapai atas berbagai aktivitas yang telah dilakukan, dapat dijelaskan bahwa kinerja keuangan adalah suatu analisis yang dilakukan untuk melihat sejauh mana suatu perusahaan telah melaksanakan dengan menggunakan aturan-aturan pelaksanaan keuangan secara baik dan benar (Fahmi, 2012:2). 
Kinerja perusahaan dapat dilihat melalui laporan keuangan yang sering dijadikan dasar untuk menilai kinerja perusahaan. Kinerja keuangan dapat diukur dengan Return On Assets (ROA) (Rimardhani,dkk 2016). Return on Assets (ROA) menurut Kasmir (2012:201) adalah rasio yang menunjukan hasil (return) atas jumlah aktiva yang digunakan dalam perusahaan. ROA menunjukkan kemampuan perusahaan dengan menggunakan seluruh aktiva yang dimiliki untuk menghasilkan laba setelah pajak. Semakin besar ROA, maka semakin efesien aktiva perusahaan atau dengan kata lain dengan jumlah aktiva yang sama bisa dihasilkan laba lebih besar dan sebaliknya.

\section{METODE PENELITIAN}

Pendekatan kuantitatif digunakan untuk menjawab permsalahan dalam penelitian ini. Sebanyak 43 perusahaan perbankan sebagai populasi penelitian. Sedangkan teknik pengambilan sampel yang digunakan yaitu dengan purpose sampling, dan diperoleh jumlah sampel 25 perusahaan (Sugiyono, 2012:81). Teknik pengumpulan data dilakukan dengan dokumentasi, yaitu dengan mengumpulkan dan menganalisis laporan-laporan keuangan yang telah dipublikasikan oleh BEI.

Untuk menjawab permasalahan dan hipotesis penelitian, digunakan teknik analisis regresi linier berganda (Sugiyono, 2013:275). Adapun pengukuran variabel dalam penelitian ini yaitu :

Tabel 1Definisi Operasional dan Pengukuran Variabel

\begin{tabular}{|c|c|c|}
\hline Variabel & Definisi & Pengukuran \\
\hline $\begin{array}{l}\text { Dewan } \\
\left(\mathrm{X}_{1}\right)\end{array}$ & $\begin{array}{l}\text { Anggota perusahaan yang mempunyai } \\
\text { tanggung jawab dan wewenang } \\
\text { mengawasi tindakan manajemen dan } \\
\text { memberikan arahan kepada direksi } \\
\text { (Marjono dan Ningsih, 2016) }\end{array}$ & Total anggota dewan komisaris dalam perusahaan \\
\hline Dewan Direksi $\left(\mathrm{X}_{2}\right)$ & $\begin{array}{l}\text { Personil yang bertugas mengelola } \\
\text { perusahaan (Masitoh dan Hidayah, 2018) }\end{array}$ & Jumlah keseluruhan dewan direksi perusahaa \\
\hline Komite Audit $\left(\mathrm{X}_{3}\right)$ & $\begin{array}{l}\text { Anggota perusahaan yang memiliki tugas } \\
\text { dan tanggungjawab melakukan } \\
\text { pengawasan keuangan perusahaan } \\
\text { (Marjono dan Ningsih, 2016) }\end{array}$ & $\begin{array}{l}\text { Jumlah keseluruhan anggota komite audit yang } \\
\text { ada pada perusahaan. }\end{array}$ \\
\hline $\begin{array}{l}\text { Kepemilikan } \\
\text { Institusional }\left(\mathrm{X}_{4}\right)\end{array}$ & $\begin{array}{l}\text { Proporsi atas kepemilikan saham oleh } \\
\text { lembaga atau institusi pada suatu } \\
\text { perusahaan } \\
\text { (Boediono dalam Ramardhani, dkk 2016) }\end{array}$ & $\begin{array}{l}\text { INST } \\
=\frac{\text { Jumlah saham yang dimiliki institusi }}{\text { Jumlah saham yang beredar akhir tahun }} \times 10 \mathrm{C}\end{array}$ \\
\hline $\begin{array}{l}\text { Kinerja } \\
(\mathrm{Y})\end{array}$ & $\begin{array}{l}\text { Prestasi menajemen perusahaan dalam } \\
\text { menjalankan fungsi dan pengelolaan aset } \\
\text { (Sudana, 2011:22) }\end{array}$ & Return On Asset $(\mathrm{ROA})=\frac{\text { Laba Setelah Pajak }}{\text { Total Asset }}$ \\
\hline
\end{tabular}

\section{HASIL DAN PEMBAHASAN}

a. Deskripsi Variabel

Tabel 2

Hasil Perhitungan Dewan Komisaris

\begin{tabular}{lrrrr}
\hline \multicolumn{1}{c}{ Kode } & \multicolumn{4}{c}{ Dewan Komisaris } \\
\multicolumn{1}{c}{ Perusahaan } & $\mathbf{2 0 1 4}$ & $\mathbf{2 0 1 5}$ & $\mathbf{2 0 1 6}$ & $\mathbf{2 0 1 7}$ \\
\hline BBKP & 7 & 6 & 7 & 7 \\
BBMD & 4 & 4 & 4 & 4
\end{tabular}




\begin{tabular}{|c|c|c|c|c|}
\hline \multirow{2}{*}{$\begin{array}{c}\text { Kode } \\
\text { Perusahaan }\end{array}$} & \multicolumn{4}{|c|}{ Dewan Komisaris } \\
\hline & 2014 & 2015 & 2016 & 2017 \\
\hline $\mathrm{BBNI}$ & 8 & 8 & 8 & 8 \\
\hline BBNP & 4 & 4 & 4 & 4 \\
\hline BBRI & 8 & 8 & 9 & 10 \\
\hline BBTN & 6 & 7 & 7 & 8 \\
\hline BDMN & 7 & 8 & 8 & 7 \\
\hline BJBR & 7 & 4 & 5 & 5 \\
\hline BMAS & 3 & 4 & 3 & 3 \\
\hline BNBA & 3 & 3 & 3 & 3 \\
\hline BSWD & 7 & 5 & 4 & 4 \\
\hline BVIC & 4 & 4 & 4 & 4 \\
\hline MAYA & 5 & 5 & 5 & 6 \\
\hline SDRA & 4 & 4 & 4 & 4 \\
\hline BACA & 3 & 3 & 3 & 2 \\
\hline BNGA & 9 & 9 & 9 & 10 \\
\hline MEGA & 3 & 4 & 4 & 7 \\
\hline BSIM & 3 & 3 & 3 & 3 \\
\hline AGRO & 5 & 4 & 4 & 4 \\
\hline BABP & 3 & 3 & 3 & 3 \\
\hline BINA & 4 & 3 & 3 & 3 \\
\hline BTPN & 6 & 6 & 5 & 5 \\
\hline BBYP & 4 & 4 & 4 & 4 \\
\hline NISP & 8 & 8 & 8 & 8 \\
\hline PNBN & 5 & 6 & 6 & 6 \\
\hline
\end{tabular}

Hasil perhitungan menunjukkan bahwa, pada tahun 2014 perusahaan perbankan yang mempunyai jumlah dewan komisaris terbanyak yaitu Bank CIMB Niaga Tbk, dan sampai tahun 2016 menjadi perusahaan perbankan yang mempunyai jumlah dewan komisaris terbanyak. Sedangkan pada tahun 2017 Bank Rakyat Indonesia (Persero) Tbk dan Bank CIMB Niaga Tbk mempunyai dewan komisaris terbanyak.

Tabel 3 Hasil Perhitungan Dewan Direksi

\begin{tabular}{lrrrr}
\hline \multicolumn{1}{c}{ Kode } & \multicolumn{4}{c}{ Dewan Direksi } \\
Perusahaan & $\mathbf{2 0 1 4}$ & $\mathbf{2 0 1 5}$ & $\mathbf{2 0 1 6}$ & $\mathbf{2 0 1 7}$ \\
\hline BBKP & 0.845 & 0.845 & 0.845 & 0.845 \\
BBKP & 7 & 7 & 7 & 7 \\
BBMD & 5 & 5 & 5 & 5 \\
BBNI & 10 & 9 & 10 & 10 \\
BBNP & 5 & 5 & 5 & 5 \\
\hline
\end{tabular}




\begin{tabular}{lrrrr}
\hline \multicolumn{1}{c}{ Kode } & \multicolumn{4}{c}{ Dewan Direksi } \\
Perusahaan & $\mathbf{2 0 1 4}$ & $\mathbf{2 0 1 5}$ & $\mathbf{2 0 1 6}$ & $\mathbf{2 0 1 7}$ \\
\hline BBRI & 11 & 11 & 11 & 11 \\
BBTN & 6 & 8 & 8 & 8 \\
BDMN & 9 & 7 & 9 & 7 \\
BJBR & 7 & 7 & 7 & 7 \\
BMAS & 4 & 4 & 4 & 4 \\
BNBA & 3 & 3 & 3 & 3 \\
BSWD & 5 & 7 & 5 & 4 \\
BVIC & 7 & 6 & 5 & 5 \\
MAYA & 6 & 8 & 9 & 8 \\
SDRA & 6 & 6 & 7 & 7 \\
BACA & 5 & 5 & 5 & 5 \\
BNGA & 11 & 11 & 10 & 11 \\
MEGA & 9 & 10 & 8 & 7 \\
BSIM & 6 & 8 & 8 & 7 \\
AGRO & 5 & 5 & 5 & 5 \\
BABP & 6 & 5 & 5 & 4 \\
BINA & 3 & 3 & 4 & 4 \\
BTPN & 9 & 11 & 7 & 7 \\
BBYP & 5 & 5 & 5 & 5 \\
NISP & 10 & 10 & 10 & 10 \\
PNBN & 11 & 12 & 12 & 12 \\
\hline \multicolumn{1}{c}{ Sumber Data Diolah Dari } & BEI 2019 &
\end{tabular}

Diketahui bahwa perusahaan perbankan periode 2014 dengan jumlah direksi terbanyak adalah Bank Rakyat Indonesia (Persero) Tbk, Bank CIMB Niaga Tbk dan Bank Pan Indonesia Tbk. Pada periode 2015 perusahaan perbankan yang mempunyai jumlah direksi terbanyak yaitu pada Bank Pan Indonesia Tbk, dan menjadi perusahaan perbankan yang mempunyai jumlah direksi terbanyak sampai periode 2017.

Tabel 4 Hasil Perhitungan Komite Audit

\begin{tabular}{lcccl}
\hline \multicolumn{1}{c}{ Kode } & \multicolumn{4}{c}{ Dewan Komite Audit } \\
Perusahaan & $\mathbf{2 0 1 4}$ & $\mathbf{2 0 1 5}$ & $\mathbf{2 0 1 6}$ & $\mathbf{2 0 1 7}$ \\
\hline BBKP & 4 & 5 & 5 & 5 \\
BBMD & 4 & 3 & 3 & 3 \\
BBNI & 3 & 4 & 3 & 4 \\
BBNP & 3 & 3 & 3 & 3 \\
BBRI & 6 & 4 & 6 & 6 \\
BBTN & 2 & 3 & 3 & 2 \\
BDMN & 3 & 3 & 3 & 3 \\
\hline
\end{tabular}




\begin{tabular}{|c|c|c|c|c|}
\hline \multirow{2}{*}{$\begin{array}{c}\text { Kode } \\
\text { Perusahaan }\end{array}$} & \multicolumn{4}{|c|}{ Dewan Komite Audit } \\
\hline & 2014 & 2015 & 2016 & 2017 \\
\hline BJBR & 6 & 5 & 5 & 4 \\
\hline BMAS & 5 & 5 & 4 & 4 \\
\hline BNBA & 3 & 3 & 3 & 3 \\
\hline BSWD & 5 & 3 & 3 & 3 \\
\hline BVIC & 4 & 5 & 5 & 5 \\
\hline MAYA & 3 & 4 & 3 & 3 \\
\hline SDRA & 5 & 5 & 5 & 5 \\
\hline BACA & 3 & 3 & 3 & 3 \\
\hline BNGA & 6 & 6 & 4 & 6 \\
\hline MEGA & 3 & 3 & 3 & 3 \\
\hline BSIM & 4 & 3 & 3 & 3 \\
\hline AGRO & 3 & 3 & 3 & 3 \\
\hline BABP & 4 & 4 & 4 & 4 \\
\hline BINA & 4 & 4 & 4 & 4 \\
\hline BTPN & 4 & 3 & 4 & 4 \\
\hline BBYP & 4 & 4 & 4 & 4 \\
\hline NISP & 4 & 4 & 3 & 3 \\
\hline PNBN & 4 & 4 & 4 & 4 \\
\hline
\end{tabular}

Dari hasil perhitungan jumlah komite audit pada perusahaan perbankan, diketahui bahwa pada tahun 2014 yang memiliki jumlah komite terbanyak yaitu Bank Rakyat Indonesia (Persero) Tbk dan Bank CIMB Niaga Tbk. Pada tahun 2015 jumlah komite audit terbanyak adalah Bank CIMB Niaga Tbk. Sedangkan pada tahun 2016 sampai dengan 2017 jumlah komite audit terbanyak adalah Bank Rakyat Indonesia (Persero) Tbk dan Bank CIMB Niaga Tbk di tahun 2017.

Tabel 5 Hasil Perhitungan Kepemilikan Institusional

\begin{tabular}{lrrrr}
\hline \multicolumn{1}{c}{ Kode } & \multicolumn{4}{c}{ Kepemilikan Institusional } \\
Perusahaan & $\mathbf{2 0 1 4}$ & $\mathbf{2 0 1 5}$ & $\mathbf{2 0 1 6}$ & $\mathbf{2 0 1 7}$ \\
\hline BBKP & -0.225 & -0.225 & -0.225 & -0.225 \\
BBMD & -0.048 & -0.048 & -0.048 & -0.048 \\
BBNI & -0.010 & -0.222 & -0.222 & -0.008 \\
BBNP & -0.069 & -0.086 & -0.064 & -0.064 \\
BBRI & -0.246 & -0.246 & -0.246 & -0.246 \\
BBTN & -0.221 & -0.222 & -0.222 & -0.222 \\
BDMN & -0.130 & -0.130 & -0.131 & -0.102 \\
BJBR & -0.125 & -0.125 & -0.125 & -0.125 \\
BMAS & -0.058 & -0.123 & -0.123 & -0.095 \\
\hline
\end{tabular}




\begin{tabular}{lrrrr}
\hline \multicolumn{1}{c}{ Kode } & \multicolumn{4}{c}{ Kepemilikan Institusional } \\
& $\mathbf{2 0 1 4}$ & $\mathbf{2 0 1 5}$ & $\mathbf{2 0 1 6}$ & $\mathbf{2 0 1 7}$ \\
\hline BNBA & -0.041 & -0.041 & -0.041 & -0.041 \\
BSWD & -0.023 & -0.027 & -0.019 & -0.015 \\
BVIC & -0.162 & -0.162 & -0.146 & -0.149 \\
MAYA & -0.066 & -0.058 & -0.055 & -0.060 \\
SDRA & -0.108 & -0.656 & -0.656 & -0.656 \\
BACA & -0.357 & -0.125 & -0.830 & -0.477 \\
BNGA & -0.014 & -0.014 & -0.039 & -0.039 \\
MEGA & -0.238 & -0.238 & -0.238 & -0.236 \\
BSIM & -0.252 & -0.255 & -0.232 & -0.244 \\
AGRO & -0.095 & 0.941 & -0.059 & -0.061 \\
BABP & -0.344 & -0.164 & -0.210 & -0.268 \\
BINA & -0.239 & -0.239 & -0.022 & -0.022 \\
BTPN & -0.008 & -0.159 & -0.159 & -0.215 \\
BBYP & -0.018 & -0.041 & -0.052 & -0.052 \\
NISP & -0.070 & -0.070 & -0.070 & -0.070 \\
PNBN & -0.071 & -0.071 & -0.071 & -0.071 \\
\hline SiN
\end{tabular}

Sumber: Data Diolah Dari BEI,2019

Dari hasil perhitungan di atas, diketahui bahwa pada tahun 2014 perusahaan perbankan yang mempunyai kepemilikan institusional tertinggi yaitu Bank Negara Indonesia (Persero) Tbk dan Bank Tabungan Pensiunan Nasional Tbk. Pada periode 2015 perusahaan yang mempunyai nilai kepemilikan institusi tertinggi yaitu Bank CIMB Niaga Tbk. Pada periode 2016 yang mempunyai nilai kepemilikan institusi tertinggi yaitu Bank of India Indonesia Tbk. Sedangkan pada periode 2017 perusahaan yang mempunyai kepemilikan institusional tertinggi yaitu Bank Negara Indonesia (Persero) Tbk.

Tabel 6 Hasil Perhitungan Kinerja Keuangan (ROA)

\begin{tabular}{lrrrr}
\hline \multicolumn{1}{c}{ Kode } & \multicolumn{4}{c}{ Return on Asset } \\
Perusahaan & $\mathbf{2 0 1 4}$ & $\mathbf{2 0 1 5}$ & $\mathbf{2 0 1 6}$ & $\mathbf{2 0 1 7}$ \\
\hline BBKP & -2.036 & -1.991 & -1.985 & -2.894 \\
BBMD & -1.563 & -1.592 & -1.771 & -1.651 \\
BBNI & -1.585 & -1.745 & -1.723 & -1.712 \\
BBNP & -1.992 & -2.110 & -2.978 & -2.097 \\
BBRI & -1.519 & -1.539 & -1.583 & -1.589 \\
BBTN & -2.113 & -1.968 & -1.913 & -1.936 \\
BDMN & -1.863 & -1.882 & -1.795 & -1.668 \\
BJBR & -1.831 & -1.808 & -1.948 & -1.977 \\
BMAS & -2.290 & -2.124 & -1.905 & -1.940 \\
BNBA & -1.998 & -2.062 & -1.956 & -1.894 \\
\hline
\end{tabular}




\begin{tabular}{lrrrr}
\hline \multicolumn{1}{c}{ Kode } & \multicolumn{4}{c}{ Return on Asset } \\
Perusahaan & $\mathbf{2 0 1 4}$ & $\mathbf{2 0 1 5}$ & $\mathbf{2 0 1 6}$ & $\mathbf{2 0 1 7}$ \\
\hline BSWD & -1.766 & -2.155 & -0.932 & -1.553 \\
BVIC & 0.694 & -2.393 & -2.413 & -2.326 \\
MAYA & -1.919 & -1.860 & -1.870 & -2.044 \\
SDRA & -2.076 & -1.878 & -1.864 & -1.791 \\
BACA & -2.094 & -2.127 & -2.182 & -2.278 \\
BNGA & -1.998 & -2.747 & -2.065 & -1.951 \\
MEGA & -2.046 & -1.812 & -1.785 & -1.801 \\
BSIM & -2.137 & -2.178 & 1.075 & -1.980 \\
AGRO & -2.013 & -2.017 & -2.043 & -2.065 \\
BABP & -2.222 & -3.000 & -3.145 & -1.194 \\
BINA & -2.063 & -2.091 & -2.112 & -2.231 \\
BTPN & -1.604 & -1.665 & -1.688 & -2.827 \\
BBYP & -2.350 & -2.138 & -1.784 & -2.540 \\
NISP & -1.889 & -1.905 & -1.888 & -1.849 \\
PNBN & -1.825 & -2.067 & -1.898 & -2.027 \\
\hline
\end{tabular}

Sumber: Data Diolah Dari BEI,2019

Dari hasil perhitungan return on asset (ROA) yang ditunjukkan pada tabel di atas, diketahui bahwa pada periode 2014 perusahaan perbankan yang mempunyai nilai ROA terbesar yaitu Bank Victoria Tbk, pada periode 2015 yang mempunyai nilai ROA terbesar yaitu Bank Rakyat Indonesia (Persero) Tbk. Untuk periode 2016 perusahaan perbankan yang mempunyai nilai ROA terbesar yaitu Bank Sinar Mas Tbk, sedangkan periode 2017 perusahaan yang mempunyai nilai ROA terbesar yaitu Bank Rakyat Indonesia (Persero) Tbk.

\section{b. Analisis Regresi Linier Berganda}

Adapun hasil uji regresi linier berganda dalam penelitian ini adalah sebagai berikut:

Tabel 7 Hasil Regresi Linier Berganda

\begin{tabular}{lr}
\hline \multicolumn{1}{c}{ Variabel } & \multicolumn{1}{c}{$\boldsymbol{B}$} \\
\hline Konstanta & 0.336 \\
Dewan Komisaris & -2.833 \\
Dewan Direksi & 3.031 \\
Komite Audit & -1.526 \\
Kepemilikan Institusional & 0.365 \\
\hline
\end{tabular}

Sumber : Data diolah, 2019 
Dari hasil perhitungan regresi linier berganda, diperoleh persamaan sebagai berikut

$$
Y=0,336+-2,833 X_{1}+3,031 X_{2}+-1,526 X_{3}+0,365 X_{4}
$$

Penjelasan:

1. Nilai konstanta adalah 0,336 . Artinya, dengan tidak adanya pengaruh dari dewan komisaris, direksi, komite audit dan kepemilikan institusional maka nilai variabel terikat kinerja keuangan yang diukur dengan ROA tetap konstan sebesar 0,336.

2. Variabel dewan komisaris memperoleh nilai koefisien sebesar -2,833. Artinya, jika variabel dewan komisaris dinaikkan satu satuan, maka variabel kinerja keuangan (ROA) mengalami penurunan sebesar 2,833 satuan dimana faktor lain dianggap konstan.

3. Variabel direksi memperoleh nilai koefisien sebesar 3,031. Artinya, jika variabel dewan direksi dinaikkan satu satuan, maka variabel kinerja keuangan (ROA) mengalami kenaikan sebesar 3,031 satuan dimana faktor lain dianggap konstan.

4. Variabel komite audit memperoleh nilai koefisien sebesar -1,526. Artinya, jika variabel komite audit dinaikkan satu satuan, maka variabel kinerja keuangan (ROA) mengalami penurunan sebesar 1,526 satuan dimana faktor lain dianggap konstan.

5. Variabel kepemilikan institusional memperoleh nilai koefisien sebesar 0,365. Artinya, jika variabel kepemilikan institusional dinaikkan satu satuan, maka variabel kinerja keuangan (ROA) mengalami kenaikan sebesar 0,365 satuan dimana faktor lain dianggap konstan.

\section{c. Uji Simultan (Uji F)}

Tabel 8 Hasil Uji Simultan (Uji F)

\begin{tabular}{ccccccc}
\hline Model & $\begin{array}{c}\text { Sum of } \\
\text { Squares }\end{array}$ & Df & Mean Square & F $_{\text {hitung }}$ & Sign. & Keputusan \\
\hline Regression & 30.050 & 4 & 7.512 & & & \\
Residual & 135.771 & 95 & 1.429 & 5.256 & $.001^{\mathrm{b}}$ & Signifikan \\
Total & 165.821 & 99 & & & & \\
\hline
\end{tabular}

Sumber: Data diolah,2019

Diperoleh informasi bahwa nilai $F_{\text {hitung }}$ sebesar 5,256 dan tingkat signifikansisi kurang 0,05. Artinya, variabel penerapan good corporate governance yang diproksikan dengan dewan komisaris, dewan direksi, komite audit dan kepemilikan institusional berpengaruh signifikan terhadap kinerja keuangan.

\section{d. Uji Parsial (Uji t)}

Tabel 9 Hasil Uji Parsial (Uji t)

\begin{tabular}{|c|c|c|c|c|c|c|}
\hline Variabel & $\begin{array}{c}\text { Koefisien } \\
\text { Regresi (b) }\end{array}$ & Std. Error & Beta & $\mathbf{T}_{\text {hitung }}$ & Sig. & Keterangan \\
\hline Konstanta & 0.336 & 0.838 & & .401 & .690 & \\
\hline $\begin{array}{c}\text { Dewan } \\
\text { Komisaris }\end{array}$ & -2.833 & 1.065 & -.362 & -2.660 & .009 & Signifikan \\
\hline Dewan Direksi & 3.031 & 1.115 & .366 & 2.719 & .008 & Signifikan \\
\hline Komite Audit & -1.526 & 0.982 & -.150 & -1.553 & .124 & Tidak Signifikan \\
\hline $\begin{array}{l}\text { Kepemilikan } \\
\text { Institusional }\end{array}$ & 0.365 & 0.131 & .262 & 2.793 & .006 & Signifikan \\
\hline
\end{tabular}


Sumber: Data diolah, 2019

Penjelasan :

1. Nilai tingkat signifikansi variabel dewan komisaris sebesar 0,009 atau kurang dari 0,05. Artinya, secara parsial dewan komisaris memiliki pengaruh yang signifikan terhadap kinerja keuangan (ROA).

2. Nilai tingkat signifikansi dewan direksi sebesar 0,008 atau kurang dari 0,05 . Artinya, secara parsial dewan direksi memiliki pengarub yang signifikan terhadap kinerja keuangan (ROA).

3. Nilai tingkat signifikansi variabel komite audit sebesar 0,124 atau lebih dari 0,05 . Artinya, bahwa secara parsial komite audit tidak memilii pengaruh yang signifikan terhadap kinerja keuangan (ROA).

4. Nilai tingkat signifikansi variabel kepemilikan institusional sebesar 0,006 atau kurang dari 0,05 . Artinya, bahwa secara parsial kepemilikan institusional memiliki pengaruh yang signifikan terhadap kinerja keuangan (ROA).

\section{e. Pembahasan}

H1 : Dewan komisaris berpengaruh signifikan terhadap kinerja keuangan perusahaan perbankan di BEI periode 2014-2017.

Dari hasil analisis data, diperoleh hasil bahwa ada pengaruh negatif signifikan dewan komisaris terhadap kinerja keuangan perusahaan. Selaras dengan hasil penelitian yang dilakukan Rimardhani, dkk (2016), dimana dewan komisaris mempunyai kontribusi negatif yang signifikan terhadap kinerja keuangan. Hal ini diakibatkan karena akan memicu timbulnya konflik yang diakibatkan karena adanya miskomuniasi jika dewan komisaris dalam suatu perusahaan terlalu banyak. Hasil diperkuat dengan penelitian yang dilakukan Putri (2016), dimana ukuran dewan komisaris terhadap kinerja keuangan memiliki pengaruh negatif dan signifikan.

H2 : Dewan direksi berpengaruh signifikan terhadap kinerja keuangan perusahaan perbankan di BEI periode 2014-2017.

Hasil analisis data menunjukkan bahwa dewan direksi terhadap kinerja keuangan perusahaan perbankan di BEI periode 2014-2017 memiliki pengaruh positif signifikan. Selaras dengan penelitian yang dilakukan Aprianingsih (2016), dimana dewan direksi memiliki pengaruh positif signifikan pada kinerja keuangan. Terkait demikian, jumlah dewan direksi yang banyak dalam perusahaan, akan berpengaruh pada semakin baiknya kinerja keuangan. Namun, jumlah dewan direksi yang terlalu banyak juga memberikan dampak negatif, yaitu adanya kontrol yang berlebih terhadap kegiatan operasional perusahaan. Diperkuat dengan hasil penelitian Putri (2016), dimana direksi terhadap kinerja keuangan memiliki hubungan positif signifikan.

H3 : Komite audit berpengaruh signifikan terhadap kinerja keuangan perusahaan perbankan di BEI periode 2014-2017.

Dari hasil analisis data, diperoleh hasil bahwa komite audit masih belum mempengaruhi kinerja keuangan. Selaras dengan penelitian Rimardhani, dkk (2016), dimana tidak ada pengaruh antara komite audit dengan kinerja keuangan. Artinya bahwa banyak atau tidaknya komite audit dalam perusahaan terutama dalam perusahaan perbankan, tidak berpengaruh pada kinerja keuangan yang baik. Karena keberadaan komite audit dalam perusahaan tidak menjamin efektivitas perusahaan, melainkan hanya sebatas pemenuhan regulasi yang ada. Didukung penelitian Herawanto et al (2017), dimana komite audit dengan kinerja keuangan masih belum memiliki pengaruh yang berarti. 
H4 : Kepemilikan institusional berpengaruh signifikan terhadap kinerja keuangan perusahaan perbankan di BEI periode 2014-2017.

Dari hasil analisis data diperoleh informasi bahwa kepemilikan institusional terhadap kinerja keuangan memiliki pengaruh positif signifikan. Selaras dengan hasil penelitian Putri (2016), dimana kepemilikan institusional terhadap kinerja keuangan memiliki pengaruh positif signifikan. Artinya semakin tinggi tingkat kepemilikan institusional dalam suatu perusahaan, maka kinerja keuangan akan semakin baik. Hal ini diakibatkan karena adanya pihak luar perusahaan yang melakukan pengawasan, sehingga adanya tekanan dalam perusahaan untuk mencapai target yang diharapaknan.

H5 : Dewan komisaris, dewan direksi, komite audit dan kepemilikan institusional berpengaruh signifikan terhadap kinerja keuangan perusahaan perbankan di BEI periode 2014-2017.

Berdasarkan hasil penelitian dan alisis data menunjukkan bahwasannya secara simultan penerapan GCG memiliki pengaruh yang signifikan terhadap kinerja keuangan perusahaan perbankan di BEI periode 2014-2017. Hasil selaras dengan penelitian Putri (2016), dimana penerapan GCG mempunyai pengaruh yang signifikan terhadap kinerja keuangan perusahaan perbankan periode 2010-2014. Diperkuat dengan hasil penelitian yang dilakukan Marjono dan Ningsih (2016), dimana penerapan GCG secara konsisten akan dapat membantu tercapainya tujuan perusahaan dalam memperoleh keuntungan.

\section{SIMPULAN}

Dari hasil analisis data, diketahui bahwa hanya komite audit yang tidak berpengaruh signinifikan, dewan komisaris berpengaruh negatif signifikan, dewan direksi dan kepemilikan institusional berpengaruh positif signifikan. Hasil lain menunjukkan bahwa secara simultan penerapan GCG memiliki pengaruh signifikan terhadap kinerja keuagan.

\section{DAFTAR PUSTAKA}

Agoes, dan Ardana. (2013). Etika Bisnis dan profesi, Edisi Revisi. Jakarta: Salemba Empat.

Aprianingsih, A. (2016). Pengaruh Penerapan Good Corporate Governance, Struktur Kepemilikan dan Ukuran Perusahaan Terhadap Kinerja Keuangan Perbankan. Jurnal Profita Volume 1 Nomor 4.1-16.

Budiyono, B., \& Maryam, D. (2017). Disclosure of Corporate Social Responsibility (CSR) Through Company Characteristics at Company Listed on LQ45 Indonesia Stock Exchange (IDX). International Journal of Economics, Business and Accounting Research (IJEBAR), 1(02).

Budiyono, B., \& Wulansari, F. A. (2018). Good Corporate Governance Management On Corporate Values (Empirical Study on Chemical Companies listed on the Indonesia Stock Exchange Period 2013-2015). International Journal of Economics, Business and Accounting Research (IJEBAR), 2(01).

Fahmi, I. (2012). Analisis Laporan Keuangan. Jakarta: Kencana.

Herawanto, et al. (2017). The Influence of Corporate Governance and Ownership Structure on Profitability. International Journal of Scientific and Research Publications, Volume 7, Issue 7, July 2017, hal 7-15. 
Suwasono H, Pengaruh Corporate Governance Terhadap Nilai Perusahaan Dengan Kinerja Keuangan Sebagai Variabel Intervening Pada Perusahaan Manufaktur Yang Terdaftar Di Bursa Efek Indonesia ...

Istighfarin, dan Wirawati. (2015). Pengaruh Good Corporate Governance Terhadap Profitabilitas Pada Badan Usaha Milik Negara (BUMN). E-Jurnal Akuntansi Universitas Udayana Vol.13.No.2 ISSN: 2302-8556, 564-581.

Kasmir. (2015). Analisis Laporan Keuangan. Jakarta: PT. Raja Grafindo Persada.

Marjono, dan Ningsih. (2016). Pengaruh Good CorporateGovernance Terhadap Kinerja Keuangan (Studi Empiris Pada Perusahaan MAnufaktur Yang Terdaftar Di Bursa Efek Indonesia PAda Tahun 2013). Jurnal Sekolah Tinggi Ilmu Ekonomi Pontianak.

Masitoh, dan Hidayah. (2018). Pengaruh Penerapan Good Corporate Governance Terhadap Kinerja Perusahaan (Studi Empirik Pada Perusahaan Perbankan di BEI tahun 2014 - 2016). Jurnal Tekun. Vol 1. No. 1., 49-59.

Putri, D. (2016). Pengaruh Penerapan Good Corporate Governance Terhadap Kinerja Keuangan (Studi Empiris Pada Perusahaan Perbankan yang Terdaftar di BEI Tahun 2010-2014). Naskah Publikasi Program Studi Manajemen Fakultas Ekonimi dan Bisnis Universitas Muhammadiyah Surakarta.

Ramardhani, dkk. (2016). Pengaruh Mekanisme Good Corporate Governance Terhadap Profitabilitas Perusahaan (Studi Pada Perusahaan Bumn Yang Terdaftar Di Bei Tahun 2012-2014). Jurnal Administrasi Bisnis (JAB)|Vol. 31 No. 1, 167-175.

Sudana, I. M. (2011). Manajemen Keuangan Perusahaan Teori dan Praktik . Surabaya: Erlangga.

Sugiyono. (2012). Metode Penelitian Kuantitatif, Kualitatif dan R\&D. Bandung: Alfabeta.

Sugiyono. (2013). Metode Penelitian Kuantitatif, Kualitatif dan R\&D. Bandung: Alfabeta.

Sutedi, A. (2012). Good Corporate Governance. Jakarta: Sinar Grafika. 